\title{
Gebelerdeki Asemptomatik Bakteriüri: Sıklıg̃ı, Antimikrobiyal Duyarlılık Profili, Etken Mikroorganizmalar ve Risk Faktörleri
}

\section{Asymptomatic Bacteriuria in Pregnant Women: Frequency, Antimicrobial Susceptibility Profile, Causative Microorganisms and Risk Factors}

\author{
Semih TOKAK'(IID), Jule ERIC COORASANLI²(ID)
}

\author{
${ }^{1}$ KTO Karatay Üniversitesi Tıp Fakültesi, Tıbbi Mikrobiyoloji Anabilim Dalı, Konya, Türkiye \\ ${ }^{2}$ Necmettin Erbakan Üniversitesi Tıp Fakültesi, Kadın Hastalıkıarı ve Dog̃um Anabilim Dalı, Konya, Türkiye
}

\section{Makale atıfı: Tokak S, Eriç Horasanıl J. Gebelerdeki asemptomatik bakteriüri: sıklığı, antimikrobiyal duyarılık profili, etken mikroorganizmalar ve risk} faktörleri. FLORA 2020;25(4):555-62.

\section{ÖZ}

Giriş: Asemptomatik bakteriüri (ASB) idrar yolu infeksiyonlarının belirgin belirtileri olmadan idrarda bakteri varlığı olarak tanımlanmaktadır. Asemptomatik bakteriüri hamilelik sırasında ortaya çıkmakta olup hamilelik sırasında tedavi edilmediğinde olumsuz maternal ve perinatal sonuçlarla ilişkilendirilmektedir. Bu çalışmadaki amacımı bölgemizde kadın hastalıkları ve doğum kliniğine başvuran gebelerdeki ASB görülme sıklığını, ilişkili risk faktörlerini, bakteriüriye sebep olan mikroorganizmaları ve antibiyotik duyarlııklarını belirlemektir.

Materyal ve Metod: Üniversite hastanemizin kadın hastalıkları ve doğum kliniklerine 1 Ocak 2017-1 Ocak 2019 tarihleri arasında başvuran 18 yaş ve üstü tüm gebeler dahil edildi. Hastalara ait demografik özellikler, risk faktörleri, laboratuvar bulguları, hastaların klinik kayıtlarından elde edildi. idrar örnekleri aseptik koşullarda toplandı. Elde edilen örnekler rutin makroskopi, mikroskopi incelemesi ve uygun besiyerlerine ekilerek kültüre edildi. Kültürde anlamlı üreme olan plaklardaki mikrobiyal izolatlar konvensiyonel metotlar ile tanımlandı. Tüm bakteriyel izolatların antimikrobiyal duyarlııklarının belirlenmesi için Kirby Bauer disk difüzyon yöntemi kullanıldı. Veriler SPSS versiyon 24 yazılımı ile analiz edildi ve tüm durumlarda, 0.05 'in altındaki $p$ değerleri istatistiksel olarak anlamlı kabul edildi.

Bulgular: Çalışmaya toplam 410 gebe dahil edildi. Kültürde üreme olan 32 hasta vaka grubuna, kültürde üreme olmayan 378 hasta ise kontrol grubuna dahil edildi. Ortalama yaş $30.29 \pm 5.61$ (18-45 yaş) olarak bulundu. ASB görülme sıklı̆ı \%7.8 idi. Doğum sayısı ile ASB arasında istatistiksel anlamlı bir fark saptandı. istatistiksel analiz sonucuna göre; 2 doğum yapan gebelerin, 1 doğum yapanlara göre ASB'ye yakalanma riski 0.056 kat, 3 doğum yapan gebelerin, 2 doğum yapanlara göre ASB'ye yakalanma riskinin ise 0.045 kat arttığı belirlendi (Doğum sayısı; 1; OR: 0,148; \% 95 GA: (0.023-0.957), 2; OR: 0,056; \% 95 GA: (0.006-0.580), 3; OR: $0.045 \% 95$ $G A:(0.002-0.870) ; P<.005)$. izole edilen mikroorganizmalar içerisinde en baskın tür Escherichia coli (\%59.4) olup bunu Enterobacter aerogenes (\%15.7), Staphylococcus aureus (\%9.4) izledi. İolatlar, nitrofurantoin (\%93.75), amikasin (\%93.75), tetrasiklin (\%93.10) ve trimetoprim-sülfametoksazol (\%87.5) antibiyotiklere duyarlı idi.

Sonuç: ASB gebelerde önemli oranda yüksektir. Düşük ve erken doğum için bir risk faktörü olan ASB varlığının gebelik sırasında taranması ve tedavi edilmesi önemlidir. Gebelerin ASB açısından taranması ve tedavi edilmesi, gebelik komplikasyonları ve ilişkili advers doğum sonuçlarının önlenmesini de sağlayacaktır. Gebelerin tedavisinde antibiyotik duyarlıık testi sonuçları mutlaka dikkate alınmalıdır.

Anahtar Kelimeler: Asemptomatik bakteriüri; Antimikrobiyal duyarlılı; Gebelik; Risk faktörleri

Geliș Tarihi/Received: 04/11/2019 - Kabul Ediliș Tarihi/Accepted: 13/04/2020

${ }^{\bullet}$ Telif Haklı 2020 Flora. Makale metnine www.floradergisi.org web adresinden ulașilabilir. 


\title{
ABSTRACT \\ Asymptomatic Bacteriuria in Pregnant Women: Frequency, Antimicrobial Susceptibility Profile, Causative Microorganisms and Risk Factors
}

\author{
Semih TOKAK', Jule ERIÇ HORASANLI²
}

\author{
${ }^{1}$ Department of Medical Microbiology, School of Medicine, KTO Karatay University, Konya, Turkey \\ ${ }^{2}$ Department of Gynecology and Obstetrics, School of Medicine, Necmettin Erbakan University, Konya, Turkey
}

\begin{abstract}
Introduction: Asymptomatic bacteriuria (ASB) is defined as the presence of bacteria in the urine without significant symptoms of urinary tract infections. ASB occurs during pregnancy and is associated with negative maternal and perinatal outcomes when not treated during pregnancy. The aim of this study was to determine the frequency of ASB, related to risk factors, microorganisms causing bacteriuria and antibiotic susceptibility in pregnant women who presented to the gynecology and obstetrics clinic in our region.
\end{abstract}

Materials and Methods: All pregnant women aged 18 years and over who were admitted to the gynecology and obstetrics clinics of our university hospital between January 1, 2017 and January 1, 2019 were included. Demographic characteristics, clinical risk factors, laboratory findings, and clinical records of the patients were obtained. Urine was collected aseptically. Obtained samples were cultured by routine macroscopy, microscopy examination and appropriate media. Microbial isolates were detected by conventional methods. Kirby Bauer disc diffusion method was used to determine the antimicrobial susceptibility of all bacterial isolates. Data were analyzed with SPSS version 24 software and in all cases, $p$ values less than 0.05 were considered statistically significant.

Results: A total of 410 pregnant women were included into the study. Thirty-two patients with ASB were included in the case group and the remaining 378 patients without ASB were included in the control group. Mean age was 30.29 \pm 5.61 years (18-45 years). The prevalence of asymptomatic bacteriuria was $7.8 \%$. There was a statistically significant difference between the parity and ASB. According to the result of statistical analysis, the risk of having ASB in pregnant women who have already given two births has proved a 0.056 fold increase compared with the women who have given only one birth and a 0.045 fold increase for the pregnant women who have given three births compared with the pregnant women who have given two births (Parity; 1; OR: 0.184; 95\% Cl: (0.023-0.957), 2; OR: 0.056; 95\% Cl: (0.006-0.580), 3; OR: 0.045 95\% Cl: (0.002 p<.005). The most common microorganisms were Escherichia coli (59.4\%) followed by Enterobacter aerogenes (15.7\%) and Staphylococcus aureus (9.4\%). The isolates showed susceptibility to commonly used antimicrobials such as nitrofurantoin (93.75\%), amikacin (93.75\%), tetracycline (93.10\%) and trimethoprim-sulfamethoxazole (87.5\%).

Conclusion: The prevalence of ASB is significantly higher in pregnant women. It is important to screen and treat the disease during pregnancy because it causes a clinical picture that poses a risk for miscarriage and preterm birth. Screening and treatment of pregnant women in terms of ASB will also prevent pregnancy complications and associated adverse birth outcomes. Antibiotic susceptibility test results should be considered in the treatment of pregnant women.

Key Words: Asymptomatic bacteriuria; Antimicrobial susceptibility; Pregnancy; Risk factors

\section{GíRiș}

İdrar yolu infeksiyonu (IYE) insan popülasyonundaki en yaygin bakteriyel infeksiyonlardan birisi olup hamilelikte sık görülmektedir. IYE, üst solunum yolu infeksiyonlarından sonra en sik görülen infeksiyondur ${ }^{[1]}$. İdrar yolu infeksiyonu, semptomatik (sistit, pyelonefrit) veya asemptomatik olması açısından önemlidir ${ }^{[1,2]}$. Gebelik sırasındaki idrar yolu infeksiyonlarının çoğu asemptomatiktir, ancak tedavi edilmezse prematürite, düșük doğum ağırlığı, hipertansiyon ve fetal mortalite oranlarında artıs gibi ciddi komplikasyonlara yol açabilmekte$\operatorname{dir}^{[3]}$. Gebelikte olușan üreter dilatasyonu, üretral peristaltizmde ve mesane tonusundaki azalma, plazma volumünün artıșı, idrar konsantrasyonunun azalması, idrar östrojeninin ve progestinin artması gibi fizyolojik ve anatomik değisiklikler infeksiyon riskini arttırmaktadır ${ }^{[4]}$. Asemptomatik bakteriüri, üriner sisteme ait lokal veya sistemik herhangi bir semptomu olmayan hastada orta akım idrar kültüründe en az $10^{5} \mathrm{cfu} / \mathrm{mL}$ mikroorganizma tespit edilmesi seklinde tanımlanmaktadır. Gebelerde ASB \%2-10 oranında görülmekte ve tedavi edilmezse bu gebelerin \%30-40'inda pyelonefrit dahil semptomatik üriner sistem infeksiyonu gelisebileceği bilinmektedir ${ }^{[5]}$.

Gebeler arasında ASB görülme sıklı̆ğındaki hız1 artıș birkaç faktör ile ilișkilidir. Bu faktörler, IYYE öyküsü, yas, düsüuk sosyoekonomik durum, multiparite, düșük eğitim düzeyi, coklu gebelik, ileri 
gebelik yașı, cinsel aktivite, kötui sağlık hizmetleri, genel hijyen uygulama eksikliği, gebelikte diyabet, anemi ve kateterizasyon öyküsüdür ${ }^{[6]}$.

Son yıllarda yapilan calısmalar, hem gram-negatif hem de pozitif bakterilerin, gebelik sırasında ASB'den büyük ölçüde sorumlu olduğunu göstermiștir. Gebeler arasında ASB'den sorumlu en yaygin bakteriler E. coli, Proteus spp., Klebsiella spp., Pseudomonas spp., Enterococcus spp., S. aureus ve koagülaz negatif stafilokoklardir [6]. $E$. coli, gebeler arasında ASB'ye neden olan en baskın bakteridir ${ }^{[7,8]}$. Streptococcus agalactiae (grup B Streptococcus) kaynaklı ASB, kötü obstetrik sonuçarla ilișkilendirilmiștir. S. agalactiae'nın kadın genitoüriner sistemde kolonize olduğu ve doğumdan önce, doğum sirasında veya sonrasında yenidoğana geçtiği bilinmektedir ${ }^{[9]}$.

Asemptomatik bakteriüri tanısı için altın standart olan idrar kültuirünün gebelerde tarama amaç kullanılması, erken tanı ile ilerde ortaya cıkabilecek komplikasyonların önlenmesini sağlaması açısından önemlidir. Prospektif, karșılaștırmalı klinik çalıșmalar, ASB'nin gebelikte antimikrobiyal tedavisinin, piyelonefrit riskini \%20 ila \%30'dan, \%1-4'e kadar düșürdüğuinü, düșük doğum ağırlıklı bebeklerin doğumunu ve erken doğum sıklığını azalttığını bildirmistirr ${ }^{[10]}$. Gebeliğin erken döneminde en az bir kez idrar kültürü ile bakteriüri taranması önerilmekte, böylece verilen uygun antibiyotik tedavisinin, infeksiyonun ilerlemesini önleyeceği düșuinülmektedir ${ }^{[10]}$. Selektif beta laktamlar, nitrofurantoin, kinolonlar ve ko-trimoksazol içeren antimikrobiyal ajanlar gebelik sirasında tercih edilmektedir ${ }^{[10]}$. Bununla birlikte, ilac direncinin ortaya çkması, antibiyotik seçimini sinırlamaktadir.

$\mathrm{Bu}$ calıșmadaki amacımız, kadın hastalıkları ve doğum kliniğine gelen gebelerdeki ASB görülme sıklığını, risk faktörlerini, etiyolojik ajanları ve mikroorganizmaların antibiyotik duyarlılıklarını belirlemektir.

\section{MATERYAL ve METOD}

Bu çalıșmada, KTO Karatay U̇niversitesi Medicana Tıp Fakültesi Hastanesi kadın hastalıkları ve doğum kliniğine 01.01.2017-01.01.2019 tarihleri arasında gebelik kontrolüne gelen 410 (kültürde üreme olan hastalar vaka grubuna, kültuirde üreme olmayan hastalar kontrol grubuna dahil edildi) gebenin verileri retrospektif olarak incelendi. Calıș- mamızda; idrar yolları infeksiyonu bulguları (dizüri, sıklık ve aciliyet) olmayan, ağrılı idrar yapma, idrar kaçırma ve vajinal akıntı ile kötü koku semptomları olan hastalar, aktif antibiyotik kullanan veya son bir ay içerisinde kullanmıș olan hastalar, böbrek hastalığı, böbrek tașı öyküsü, üriner sistem ameliyatı olan hastalar calıșma dıșı bırakıldı. Katılımcıların yașı, doğum sayısı ve düșük sayısı gibi demografik veriler ile üriner sistem infeksiyonuna yönelik klinik ve laboratuvar bulguları hazırlanan hasta takip formuna kaydedildi. Hastaların idrar örnekleri, perine temizliği yapıldıktan sonra sabah ilk idrardan, steril kaplar içerisine, orta akım idrar örneği olacak șekilde alındı. Alınan örneklerin kültürü hastanemiz Mikrobiyoloji laboratuvarında yapıldı. Alınan örneklere mikroskopi ve kültür yapıldı. İdrar örnekleri \%5 koyun kanl agar ve Mac-Conkey agar besiyerlerine ekilerek $37^{\circ} \mathrm{C}$ 'de 24 saat inkübasyona birakıld1. Negatif olan örnekler 24 saat daha enkübe edildi. Sonuçlarda tek organizmanın $>10^{5} \mathrm{cfu} / \mathrm{mL}$ miktarında tespit edilmesi bakteriüri olarak kabul edildi. Üreme olmayan plaklar steril olarak kabul edildi. Mikroorganizmalar, koloni karakteristiklerine bakılarak, gram boyama yapilarak ve biyokimyasal testler kullanılarak tanımlandı. İzole edilen bakterilerin antibiyotik duyarlllk testleri Kirby-Bauer disk difüzyon metodu kullanılarak gerçekleștirildi. Calıșmada toplam 16 adet antibiyotik diski kullanıldı.

$\mathrm{Bu}$ diskler sırasıyla amikasin $(30 \mu \mathrm{g})$, amoksisilin/klavulanik asit (20/10 $\mu \mathrm{g})$, siprofloksasin (300 $\mu \mathrm{g})$, vankomisin $(30 \mu \mathrm{g})$, nitrofurantoin (300 $\mu \mathrm{g})$, seftriakson $(30 \mu \mathrm{g})$, sefuroksim $(30 \mu \mathrm{g})$, tetrasiklin $(5 \mu \mathrm{g})$, seftazidim $(30 \mu \mathrm{g})$, teikoplanin (30 $\mu \mathrm{g})$ trimethoprim-sülfametoksazol $(1.25 / 23.75 \mu \mathrm{g})$, gentamisin $(120 \mu \mathrm{g})$, streptomisin $(300 \mu \mathrm{g})$, kloramfenikol $(30 \mu \mathrm{g})$, eritromisin $(15 \mu \mathrm{g})$, penisilin (30 $\mu \mathrm{g}$ ) olarak belirlendi. İzole edilen sușlardan hazırlanan, bulanıklıkları 0.5 McFarland standardına ayarlanmıș süspansiyonlar Mueller-Hinton agara ekildi. Ekimden sonra besiyeri üzerine antibiyotik diskleri yerleștirilerek $37^{\circ} \mathrm{C}$ 'de $18-20$ saat inkuibasyona birakıld1. Kontrol olarak Enterococcus faecalis ATCC ${ }^{\circledR} 29212$ ve Staphylococcus aureus ATCC $^{\circledR} 25923$ standart sușları kullanıldı. İnkübasyon periyodunun ardından olușan zon çapları ölçülerek kaydedildi. Zon çapları ölçülen mikroorganizmaların antibiyotik duyarlılıkları "Clinical and Laboratory Standards Institute (CLSI)" kriterlerine göre değerlendirildi ${ }^{[11]}$. 
Calıșma ve veri toplama, KTO Karatay Üniversitesi İlaç ve Tıbbi Cihaz Dıșı Araștırmalar Etik Kurulundan (Say1: 41901325-050.99, Tarih: 29.11.2018) onay alınarak gerçekleștirildi. Verilerin değerlendirilmesinde SPPS 24 (IBM Corp. Released 2016. IBM SPSS Statistics for Windows, Version 24.0. Armonk, NY: IBM Corp.) istatistik paket programı kullanıldı. Değișkenlere ait ortalama \pm standart sapma ile yüzde ve frekans değerleri kullanıldı. Ayrıca parametrik testlerin ön sartlarından varyansların homojenliği "Levene" testi ile kontrol edildi. Normallik varsayımına ise "Shapiro-Wilk" testi ile bakıldı. İki grup arasındaki farkllıklar değerlendirilmek istendiğinde parametrik test ön sartlarını sağladığı durumda "Student's t Test"; sağlamadığında ise "Mann Whitney-U testi" kullanıldı. Kategorik değișkenler arasındaki ilișkiler Fisher's Exact Test ve Ki Kare testi ile analiz edildi. Beklenen frekansların \%20'den küçük olduğu durumlarda bu frekansların analize dahil edilmesi için "Monte Carlo Simulasyon Yöntemi" ile değerlendirme yapıldı. Calıșmada bağımsız değiskenler ve bağımlı değișken arasındaki ilișkinin modeli de ortaya konmak için Binary Lojistik Regresyon analizi kullanıldı. İstatistiksel anlamlılık düzeyi $\mathrm{p}<0.05$ olarak kabul edildi.

\section{BULGULAR}

Calıșmamız retrospektif olup, calıșma kapsamına bir araștırma hastanesinin kadın hastalıkları ve doğum polikliniğine Ocak 2017 ve Ocak 2019 tarihleri arasında IYE belirtileri ve semptomları olmayan 410 gebe dahil edilmiștir. İdrar kültüründe üreme olan 32 hasta olgu grubunda, kültürde üreme olmayan 378 hasta kontrol grubunda yer almıștır. Calıșmaya dahil edilen gebelerin yașlar1 18 ile 45 arasında değișmektedir. Calıșmaya dahil edilen 410 gebeden, 212'si (\%51.7) birinci trimester; 114'ü (\%27.8) ikinci trimester, ve 84'ü (\%20.5) üçüncü trimesterde idi. ASB saptanan gebelerin 16 tanesi birinci trimester, 11 tanesi ikinci trimester ve 5 tanesi üçünü trimesterde olup, gebelik haftası ile ASB arasında istatistiki olarak anlamlı bir fark saptanmamıștır (p> 0.05). Olgu grubunun yas ortalaması $26.4 \pm$ 5.8 , kontrol grubunun yas ortalaması ise $27.8 \pm$ 6.8 olarak belirlenmis olup aralarında istatistiksel olarak anlamlı bir fark saptanmamıștır ( $p>0.05$ ). Calıșmamızda ilk kez gebe olanların sayısı 155
(\%41.7), 2 ve daha fazla gebelik sayısı olanların ise 217 (\%58.3) olup, gebelik sayısı ile ASB görülme oranları karșılaștırıldığında istatistiksel olarak anlamlı bir fark saptanmamıstır ( $p>0.05$ ). ASB saptanan gebelerin $15^{\prime} \mathrm{i}$ primipar, 14 'ü ise multipar olup doğum sayısı ile ASB arasında istatiksel olarak anlamlı bir fark saptanmıștır (1. Doğum; OR: 0.148; \%95 GA: (0.023-0.957); $\mathrm{P}<.005$, 2. Doğum; OR: 0.056; \%95 GA: (0.006-0.580), 3. Doğum; OR: $0.045 \% 95$ GA: $(0.002-0.870)$. Buna göre; 2 doğum yapanların 1 doğum yapanlara göre ASB'ye yakalanma riski 0.056 kat, 3 doğum yapanların 2 doğum yapanlara göre ise 0.045 kat arttığ 1 belirlenmiștir. ASB saptanan gebelerden 28'inde daha önce IYE öyküsü varken, 4'ünde İYE öyküsü mevcut olmayıp, IYYE gecmiși ile ASB görülme oranı arasında anlamlı bir fark saptanmamıștır ( $p>0.05$ ). (Tablo 1).

Calıșmamızda ASB etkeni olarak en sık $E$. coli 19 (\%59.4) izole edilirken bunu Enterobacter aerogenes 5 (\%15.7), S. aureus 3 (\%9.4) izlemistir (Tablo 2). Gram-negatif bakterilerin tamamı (28) seftazidim, siprofloksasin ve seftriaksona duyarliyken, diğer antibiyotikler için duyarllılk oranlar1 sırasıyla; gentamisin (\%96.4) ve tetrasiklin (\%96.4) amikasin (\%92.8), amoksisilin-klavulanik asit (\%92.8) nitrofurantoin (\%92.8) ve trimetoprim-sülfametoksazol (\%85.7) olarak belirlenmiștir. Etken olarak izole edilen gram-pozitif bakterile$\mathrm{rin}^{[4]}$, ise tamamı kloramfenikol, nitrofurantoin, siprofloksasin ve seftriakson antibiyotiklerine $\mathrm{du}$ yarll1.k gösterirken, diğer antimikrobiyaller için duyarlllk oranları sırasıyla amikasin (\%75), tetrasiklin (\%75) ve trimetoprim-sülfametoksazol (\%75) ve eritromisin (\%25) olarak bulunmustur. (Tablo 3).

\section{TARTIŞMA}

Gebelikte görülen anatomik ve fizyolojik değișiklikler üriner sistem infeksiyonuna yatkınlığı arttıran bașlica sebeplerdir. ASB, gebelerde yaygın görülen bir infeksiyondur. Tedavi edilmediği takdirde piyelonefrit, preterm doğum ve düşük doğum ağırlığı dahil gebelik komplikasyonlarına ve advers doğum sonuçlarına sebep olabilmektedir ${ }^{[5]}$. ASB sıklığ1 ve izolatların mevcut antimikrobiyal direnc profilini bilmek önem tașımaktadır.

Gebelerdeki ASB risk faktörlerini araștırdığımız bu calıșmada doğum sayısı (1. Doğum \%95, 2. Doğum \%95, 3. Doğum \%95 risk faktörü olarak 


\begin{tabular}{|c|c|c|c|c|c|}
\hline \multicolumn{6}{|c|}{ ASB } \\
\hline & & Var & Yok & Odds oranı (Güven aralığı: \%95) & P: Anlamlılık düzeyi \\
\hline \multirow[t]{3}{*}{ Yaş } & $18-28$ & $11(5.1)$ & 215 (94.9) & $0.49(1.890-1.960)$ & \\
\hline & $29-38$ & $14(6.5)$ & $156(93.5)$ & $1.87(1.850-1.940)$ & 0.522 \\
\hline & $39-45$ & $7(50)$ & $7(50)$ & $1.34(1.290-1.970)$ & \\
\hline \multirow[t]{3}{*}{ Gebelik haftası } & 1. trimester & $16(7.5)$ & $196(92.5)$ & $0.03(0.000-0.000)$ & \\
\hline & 2. trimester & $11(9.6)$ & $103(90.4)$ & $0.03(0.000-0.000)$ & \\
\hline & 3. trimester & $5(5.9)$ & $79(94.1)$ & $0.04(0.000-0.000)$ & 0.992 \\
\hline \multirow[t]{5}{*}{ Gebelik sayısı } & 1 & $4(2.6)$ & $151(97.4)$ & $2.5(0.40-15.43)$ & \\
\hline & 2 & $15(9.8)$ & $138(91.2)$ & $5.49(0.620-48.550)$ & \\
\hline & 3 & $9(14.3)$ & $54(85.7)$ & $15.98(0.000-250.528)$ & 0.645 \\
\hline & 4 & $3(10.3)$ & $26(89.7)$ & $6.024(0.000-111.312)$ & \\
\hline & 5 & $1(25)$ & $3(75)$ & $5.90(0.082-427.240)$ & \\
\hline \multirow[t]{3}{*}{ Doğum sayısı } & 1 & $15(9.1)$ & 150 (89.9) & $0.148(0.023-0.957)$ & \\
\hline & 2 & $10(19.6)$ & $41(80.4)$ & $0.056(0.006-0.580)$ & \\
\hline & 3 & $4(26.7)$ & $11(73.3)$ & $0.045(0.002-0.870)$ & 0.001 \\
\hline \multirow[t]{2}{*}{ IYE geçmişi } & Var & $28(20.9)$ & $106(79.1)$ & $0.03(0.000-0.000)$ & 0.999 \\
\hline & Yok & $4(1.4)$ & $272(98.6)$ & $0.03(0.000-0.000)$ & \\
\hline
\end{tabular}

$\begin{aligned} & \text { Tablo 2. ASB tanılı gebelerde izole edilen } \\
& \text { mikroorganizmaların dağılımı }\end{aligned}$
\begin{tabular}{lc} 
Bakteri & $\mathbf{n}(\%)$ \\
\hline Escherichia coli & $19(59.4)$ \\
Enterobacter aerogenes & $5(15.6)$ \\
Klebsisella pneumoniae & $3(9.4)$ \\
Proteus mirabilis & $1(3.1)$ \\
Staphlyococcus aureus & $3(9.4)$ \\
Enterococcus faecalis & $1(3.1)$
\end{tabular}

belirlenmiștir. Calıșmamızdaki ASB görülme sıklığı \%7.8 olarak belirlenmiștir. Ülkemizde yapılan calıșmalarda ASB sıklı̆̆ \%3-14 arasındaki oranlarda bildirilmiștir ${ }^{[12-16]}$. Diğer ülkelerde yapılan calıșmalarda ise ASB sıklı̆̆ı \%2-35 arasındaki oranlarda bildirilmiștir ${ }^{[17-22]}$.

Gebeleri asemptomatik bakteriüriye yatkın hale getirdiği düșünülen birçok risk faktörü vardır. Yaș, medeni durum, cinsiyet, sosyoekonomik düzey, parite ve gebelik sayısı gibi demografik özellikler ve obstetrik geçmiș, ASB görülme sıklığ1 üzerinde bir etkiye sahiptir ${ }^{[23]}$. Calıșmamızda, ASB en sık
18-38 yaș grubu arasında görülmüș olup, yas ile ASB arasında istatiksel bir farklllık saptanmamıstır. Elde edilen bulgular diğer calıșmalar ile benzerlik

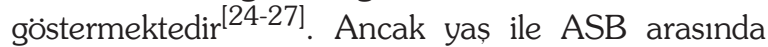
istatiksel bir farklllik saptanan calıșmalarda mevcuttur $^{[28,29]}$. $\mathrm{Bu}$ calıșmada, yașın ASB üzerine anlaml bir etkisinin olmamasının nedeni ASB'ye yatkın olan ve ileri yașta sık görülen bazı tıbbi bozuklukların dıșlanması olabilir.

Calıșmamızda, ASB ile gebelik haftası arasındaki ilișki incelendiğinde, ASB sıklıkla birinci ve ikinci trimesterde daha yüksek görülmüs olup, ASB ile gebelik haftası arasında anlamlı bir fark saptanmamıștır. Stenquist ve arkadașları gebelikte bakteriüri sıklığını 12 . haftada $\% 0.8$, gebeliğin sonunda ise \%1.93 olarak bulmuslar, ancak trimestirler arasında anlamlı bir fark saptamamıșlardır ${ }^{[28]}$. Sünbül ve arkadașları ve Tünger ve arkadașları yaptıkları calıșmalarda ASB ile gebelik haftası arasında bir ilișki saptamamıșlardır ${ }^{[30,31]}$. Kaçmaz ve arkadașları, üçüncü trimestirde ASB'nin daha fazla oranda olduğu saptamıșlardır, ancak trimestirler arası anlamlı bir fark saptamamıșlardır ${ }^{[16] .}$ 
Tablo 3. İzole edilen organizmaların duyarlılık paternleri

\begin{tabular}{|c|c|c|c|c|c|c|}
\hline Antibiyotik & $\begin{array}{l}\text { Escherichia } \\
\text { coli (n: 19) }\end{array}$ & $\begin{array}{c}\text { Enterobacter } \\
\text { aerogenes } \\
\text { (n: } 5)\end{array}$ & $\begin{array}{c}\text { Klebsisella } \\
\text { pneumoniae } \\
\text { (n: 3) }\end{array}$ & $\begin{array}{l}\text { Proteus mirabilis } \\
\text { (n: 1) }\end{array}$ & $\begin{array}{l}\text { Staphylococcus } \\
\text { aureus (n: } 3 \text { ) }\end{array}$ & $\begin{array}{r}\text { Enterococcus } \\
\text { faecalis (n: 1) }\end{array}$ \\
\hline Amikasin & $18(94.7)$ & $5(100)$ & $3(100)$ & $0(0)$ & $2(66.6)$ & $1(100)$ \\
\hline $\begin{array}{l}\text { Amoksisilin/ } \\
\text { klavulanik asit }\end{array}$ & $18(94.7)$ & $5(100)$ & - & - & $3(100)$ & $1(100)$ \\
\hline Eritromisin & - & - & - & - & $1(33.3)$ & $1(100)$ \\
\hline Gentamisin & $18(94.7)$ & $5(100)$ & $3(100)$ & $1(100)$ & - & - \\
\hline Kloramfenikol & - & - & - & - & $3(100)$ & $1(100)$ \\
\hline Nitrofurantoin & $19(100)$ & $5(100)$ & $1(33.3)$ & $1(100)$ & $3(100)$ & $1(100)$ \\
\hline Penisilin & - & - & - & - & $3(100)$ & $1(100)$ \\
\hline Seftazidim & $19(100)$ & $5(100)$ & $3(100)$ & $1(100)$ & - & - \\
\hline Seftriakson & 19 (100) & $5(100)$ & $3(100)$ & $1(100)$ & $3(100)$ & $1(100)$ \\
\hline Sefuroksim & $19(100)$ & $5(100)$ & $3(100)$ & $1(100)$ & - & - \\
\hline Siprofloksasin & $19(100)$ & $5(100)$ & $3(100)$ & $1(100)$ & $3(100)$ & $1(100)$ \\
\hline Streptomisin & - & - & - & - & $3(100)$ & $0(0)$ \\
\hline Teikoplanin & - & - & - & - & $3(100)$ & $0(0)$ \\
\hline Tetrasiklin & $18(94.7)$ & $5(100)$ & $3(100)$ & $1(100)$ & - & $0(0)$ \\
\hline $\begin{array}{l}\text { Trimetoprim/ } \\
\text { Sülfametoksazol }\end{array}$ & $17(79)$ & $4(80)$ & $2(66.6)$ & $1(100)$ & $2(66.6)$ & $1(100)$ \\
\hline Vankomisin & - & - & - & - & $3(100)$ & $1(100)$ \\
\hline
\end{tabular}

Doğum sayllarına göre ASB sıklı̆ğ incelendiğinde literatürde ASB'nin multiparlarda daha fazla görüldüğünü gösteren yayınların yanında anlamlı olmadığını ifade eden çalıșmalarda mevcuttur. Olgularımızın 165'i (\%40.2) primipar, 66'sı (\%16.1) multipar olup, ASB sıklığı ile parite arasında istatistiksel olarak anlamlı fark bulundu. Nisha ve arkadaşları yapmıs olduğu calışmada gebelerin 78'i nullipar (\%21.2), 204'ü (\%55.6) primipar, 85'i (\%23.2) multipar olarak belirtilmiștir. Calıșmalarının sonuçlarına göre ASB sıklğ̣ı ile parite arasında istatistiksel olarak fark saptamıșlardır ${ }^{[32]}$. Stenqvist ve arkadașları yapmıs olduğu calıșmada ise ASB için risk faktörü olarak multipariteyi belirlemișlerdir ${ }^{[28]}$.

Gelișen ve arkadaşları yapmıs olduğu calıșmada ise gebe ve sağlıklı kadınlardaki ASB sıklığ1 ile parite irdelendiğinde, olgu grubunda, olguların 10'u nullipar (\%28.6), 18'i primipar (\%51.4) ve 7'si (\%20) multipar iken kontrol grubunda olguların 17'si nullipar (\%48.6), 14'ü primipar \%40.0), 4'ü multipar (\%11.4) idi. Calıșmalarının sonuçlarına göre her iki grup arasında istatistiksel yön- den fark saptamamıșlardır [33]. Sarı ve arkadașları yapmıs olduğu çalıșmada gebelerin 104'ü (\%43.3) primipar, 94’ü (\%39.2) daha önce gebeliği olan ve 42'si (\%17.5) multipardı. Calıșmalarının sonuçlarına göre ASB sıklığı ile parite arasında istatistiksel olarak fark saptamamıslardır ${ }^{[12]}$. Multiparite her gebelikte infeksiyona yatkınlığa neden olup, sonucta tekrarlayan üriner sistem infeksiyonu gelișimine yol açarak calıșmamızdakine benzer sonuçlar doğurabilir. ASB ile iliskili risk faktörleri arasında IYY geçmiși gebelerin \%32.7'sinde görülmüstür ancak istatistiksel olarak fark saptanmamıștır. Yapılan diğer calıșmalarda benzer ilișki gösterilmiștir ${ }^{[34-36]}$.

Calıșmamızda en sık saptanan patojen E. coli (\%59.4) olup bunu sirasiyla, Enterobacter aerogenes (\%15.7), S. aureus (\%9.4) izlemiștir. Kamerun'da yapilan bir calıșmada E. coli \%48.6 ile en sik tespit edilen mikroorganizma iken Klebsiella pneumoniae \%14.3 ile ikinci siklikta izlenen mikroorganizma olmuștur ${ }^{[21]}$. Bir bașka calıșmada ise en sik izole edilen etkenler sırasıyla $E$. coli (\%46) ve Staphylococcus spp. (\%23.1) olarak bil- 
dirilmiștir ${ }^{[37]}$. Ülkemizde yapılan birçok çalıșmada ise en sik tespit edilen mikroorganizma $E$. coli olmuștur ${ }^{[11-16]}$. Gebelikte olușan fizyolojik değișiklikler sebebiyle idrarda östrojen konsantrasyonunun artmasiyla E. colinin patojenitesini artırıcı rol oynaması bu mikroorganizmanın bakteriüride en sik görülen bakteri olmasının nedenlerinden biridir ${ }^{[38]}$.

\section{SONUC}

ASB gebelikte yaygın görülen bir hastalık olup zamanında ve uygun sekilde tedavi edilmediğinde ciddi maternal ve fetal komplikasyonlara yol açabilen önemli bir sorundur. Gebelik sırasında bu infeksiyonlar yönünden annenin taranması ve endikasyonu olan olguların tedavi edilmesi faydalıdır. ASB taranması için altın standart yöntem idrar kültuirüdür. İdrar kültürü pozitif tespit edilenlerin klinik değerlendirmeleri de dikkate alınarak uygun antibiyotikle tedavisinin planlanması sağlanmalı, ayrıca calıșma ortamında bakteri patojenlerin türleri ve güncellenmiș antimikrobiyal direnç profili periyodik olarak izlenmelidir.

\section{ETIK KURUL ONAYI}

Calıșma için KTO Karatay Üniversitesi İlac ve Tıbbi Cihaz Dıșı Araștırmalar Etik Kurulundan onay alındı (Karar no: 41901325-050.99, Tarih: 29.11.2018).

\section{ÇIKAR ÇATIȘMASI}

Yazarlar bu makale ile ilgili herhangi bir çkar çatıșması bildirmemișlerdir.

\section{YAZAR KATKISI}

Anafikir/Planlama: ST, JEH

Analiz/Yorum: ST

Veri sağlama: JEH

Yazım: ST, JEH

Gözden Geçirme ve Düzeltme: ST, JEH

Onaylama: ST, JEH

\section{KAYNAKLAR}

1. Nicolle LE. Urinary tract infection. Crit Care Clin 2013;29(3):699-715.

2. Begum N. Clinical profile of urinary tract infection in pregnancy. Mymensingh Med J 1992;1:6-10.

3. Moghadas AJ, Irajian G. Asymptomatic urinary tract infection in pregnant women. Iran J Pathol 2009;4(3):105-8.

4. Delzell JE, Lefevre ML. Urinary tract infections during pregnancy. Am Fam Physician 2000;61:713-21.
5. Smaill FM, Vazquez JC. Antibiotics for asymptomatic bacteriuria in pregnancy. Cochrane Database Syst Rev 2015;(8):CD000490.

6. Ali IE, Gebrecherkos T, Gizachew M, Menberu MA. Asymptomatic bacteriuria and antimicrobial susceptibility pattern of the isolates among pregnant women attending Dessie referral hospital, Northeast Ethiopia: A hospital-based cross-sectional study. Turk J Urol 2018;44(3):251-60.

7. Andabati G, Byamugisha J. Microbial aetiology and sensitivity of asymptomatic bacteriuria among antenatal mothers in Mulago hospital, Uganda. Afr Health Sci 2010;10:394452.

8. Ahmed S, Shakooh S, Salati S, Muniem A. Prevalence of asymptomatic bacteriuria among pregnant women in Kashmir. Sri Lanka J Obs Gyn 2011;33:158-62.

9. Kessous $R$, Weintraub AY, Sergienko R, Lazer T, Press F, Wiznitzer $A$, et al. Bacteruria with group- $B$ streptococcus: is it a risk factor for adverse pregnancy outcomes? J Matern Fetal Neonatal Med 2012;25:1983-6.

10. Dash M, Sahu S, Mohanty I, Narasimham MV, Turuk J, Sahu R. Prevalence, risk factors and antimicrobial resistance of asymptomatic bacteriuria among antenatal women. I Basic Clin Reprod Sci 2013;2:92-6.

11. Clinical and Laboratory Standards Institute (CLSI). Performance standards for antimicrobial susceptibility testing. $26^{\text {th }}$ ed. CLSI supplement M100S. Wayne, PA: CLSI, 2016.

12. Sarı O, Aydoğan U, Alanbay I, Atacan I, Ercan CM, Mesten $Z$, ve ark. Gebelerde asemptomatik bakteriüri sıklığı. Konuralp Tıp Dergisi 2011;3:9-13.

13. Gönen i, Çelik HS, Çelik S, Köse SA. Gebelerde asemptomatik bakteriüri sıklığının araştırılması. Düzce Tıp Dergisi 2012; 14(1):6-9.

14. Aktün, LH, Karaca N, Akpak YK. Gebelik dönemindeki asemptomatik bakteriüri: görülme sıklığı, antibiyotik duyarlılı̆ı ve demografik faktörlerle ilişkisi. Bezmialem Science 2018;6(3):163-7.

15. Aşgın N, Eroğlu S, Çakmaklıoğulları EK. Gebelikte üriner sistem infeksiyonlarının ampirik tedavisinde hangi antibiyotikler ilk seçenek olmalıdır? ANKEM Derg 2018;32(3):94-102.

16. Kaçmaz B, Çakır FÖ, Aksoy A, Biri AA. Gebelerde asemptomatik bakteriüri araştırılması. Ankem Derg 2004;18(3):153-6.

17. Assefa A, Asrat D, Woldeamanuel Y, Hiwot Y, Abdelle A, Melesse T. Bacterial profile and drug susceptibility pattern of urinary tract infection in pregnant women at Tikur Anbessa specialized hospital Addis Ababa, Ethiopia. Ethiop Med I 2008;46(3):227-35.

18. Marzieh J, Mohsen S, Nasrin R, Koroosh K. Prevalence of urinary tract infection and somes factors affected in pregnant women in Iran, Karaj. Middle-East I Sci Res 2014;20(7):782-5.

19. AL-Haddad AM. Urinary tract infection among pregnant women in Al-Mukalla district, Yemen. East Mediterr Health J 2005; 11(3):505-10. 
20. Onu FA, Ajah LO, Ezeonu PO, Umeora OU, Ibekwe PC, Ajah MI. Profile and microbiological isolates of asymptomatic bacteriuria among pregnant women in Abakaliki, Nigeria. Infect Drug Resist 2015;8:231-5.

21. Tchente NC, Okalla EC, Nouwe CC, Ebong EC, Nana NT, Mboudou E. Clinical presentation, risk factors and pathogens involved in bacteriuria of pregnant women attending antenatal clinic of 3 hospitals in a developing country: a cross sectional analytic study. BMC Pregnancy Childbirth 2019;19(1):143.

22. Abdel-Aziz EM, Barnett-Vanes A, Dabour MFE, Feng C. Prevalence of undiagnosed asymptomatic bacteriuria and associated risk factors during pregnancy: a cross-sectional study at two tertiary centres in Cairo, Egypt. BMJ Open 2017;7(3):e013198.

23. Okonko IO, Ijandipe LA, Ilusanya OA, Donbraye OB, Ejembi J, Udeze AO, et al. Incidence of urinary tract infection among pregnant women in Ibadan, South-Western Nigeria. Afr J Biotechnol 2009;8(23):6649-57.

24. Imade PE, Izekor PE, Eghafona NO, Enabulele OI, Ophori E. Asymptomatic bacteriuria among pregnant women. N Amer J Med Sci 2010;2:263-6.

25. Haider $G$, Zehra $N$, Munir AA, Haider A. Risk factors of urinary tract infection in pregnancy. I Pak Med Assoc 2010;60:213-6.

26. Turpin C, Minkah B, Danso K, Frimpong E. Asymptomatic bacteriuria in pregnant women attending antenatal clinic at Komfo Anokye Teaching Hospital, Kumasi, Ghana. Ghana Med J 2007;41:26-9.

27. Al-Senani NS. Asymptomatic bacteriuria in pregnant women. Bahrain Med Bull 2011;33:1-4.

28. Stenqvist K, Dahlén-Nilsson I, Lidin-Janson G, Lincoln K, Odén A, Rignell $S$, et al. Bacteriuria in pregnancy: frequency and risk of acquisition. Am J Epidemiol 1989;192:372-9.

29. Tadesse S, Kahsay T, Adhanom G, Kahsu G, Legese H, Wahid $A$, et al. Prevalence, antimicrobial susceptibility profile and predictors of asymptomatic bacteriuria among pregnant women in Adigrat General Hospital, Northern Ethiopia. BMC Res Notes 2018;11(1):740.

30. Sünbül $M$, Birinci $A$, Koçak I, Bıldırcın D, Günaydın $M$, Leblebicioğlu H. Gebe kadınlarda asemptomatik bakteriüri sıkıı̆ı. Flora 1999;4:46-9.
31. Tünger Ö, Oruç S, Özbakkaloğlu B, Kurutepe S, Uyar Y, Çapanoğlu R. Gebelikte asemptomatik bakteriüri sıklığı. Mikrobiyol Bült 1997;31:375-81.

32. Nisha AK, Etana AE, Tesso H. Prevalence of asymptomatic bacteriuria during pregnancy in Adama city, Ethiopia. Int J Microbiol Immunol Res 2015;3:58-63.

33. Gelisen $O$, Meydanlı M, Saruhan N, Tanrıverdi HA, Haberal A. Gebelikte asemptomatik bakteriüri: Tedavi ve kontrol gruplarında gebelik sonuçlarının karşılaştırılması. T Klin J Gynecol Obst 1997;7:59-66.

34. Chandel LR, Kanga A, Thakkur K, Mokta KK, Sood A, Chauhan $S$. Prevalence of pregnancy associated asymptomatic bacteriuria: a study done in a tertiary care hospital. J Obstet Gynaecol India 2012;62(5):511-4.

35. Rohini UV, Reddy GS, Kandati J, Ponugoti M. Prevalence and associated risk factors of asymptomatic bacteriuria in pregnancy with bacterial pathogens and their antimicrobial susceptibility in a tertiary care hospital. Int I Reprod Contracept Obstet Gynecol 2017;6:558-62.

36. Rajaratnam A, Baby NM, Kuruvilla TS, Machado S. Diagnosis of asymptomatic bacteriuria and associated risk factors among pregnant women in mangalore, Karnataka, India. I Clin Diagn Res 2014;8(9):OC23-025.

37. Farazi A, Jabbarias/ M. Asymptomatic bacteriuria in pregnancy in the central region of Iran: Frequency, risk factors, and causative organisms. Clin Epidemiol Glob Health 2019;7(3);309-12.

38. Enayat K, Fariba F, Bahram N. Asymptomatic bacteriuria among pregnant women referred to outpatient clinics in Sanandaj, Iran. Int Braz J Urol 2008;34:699-707.

\section{Yazıșma Adresi/Address for Correspondence}

Arș. Gör. Semih TOKAK

Kto Karatay Üniversitesi Tip Fakültesi, Tibbi Mikrobiyoloji Anabilim Dalı, Konya-Türkiye

E-posta: semihtokak@gmail.com 